\title{
What the old right of necessity can do for the contemporary global poor
}

Given the grim statistics of extreme poverty coupled with the daunting social and economic inequalities in the world today, a growing number of moral and political philosophers have posed the question of what moral duties arise therefrom. ${ }^{1}$ Without excluding each other, two main positions can be distinguished depending on the kind of duty that they choose to emphasize. On the one hand, starting from a human rights discourse and from a Rawlsian conception of justice as the first virtue of social institutions, justice cosmopolitans have contended that, by imposing upon the global poor certain coercive rules and institutions that harm them avoidably and foreseeably, the well-off of the world are failing on their duties of justice toward them. ${ }^{2}$ On the other hand, with the minimization of human suffering as their main goal, assistance cosmopolitans have claimed that, regardless of their causal connection to the plight of the poor, the well-off have the duty to help the latter given how much they can improve their situation at a relatively small cost. ${ }^{3}$ With the exception of war cosmopolitans (who claim that global redistributive wars may be waged by the needy against the wealthy as a response to wrongful aggression ${ }^{4}$ ), and a small subset of assistance cosmopolitans (who accept that those failing on their duty to aid may be forced to act in certain circumstances 5 ), the question of what the needy may be morally permitted to do for themselves in this context has been mostly overlooked.

In this article, my purpose is to focus on that question and to advance the following answer: that, given some individually necessary and jointly sufficient conditions, a chronically deprived agent has a right of necessity to take, use and/or occupy whatever material resources are required to guarantee her self-preservation, or the means necessary to acquire them. These conditions are that the need in question is basic, the person in need does not violate other equally important moral interests to exercise her right, and it is a last resort. The object of this right may thus include the property of third parties, but also a physical space to be and to live in.

The idea of a morally permissible right of the poor to take someone else's property to get out of their plight is not new. On the contrary, it has a long philosophical pedigree that goes back to medieval Christian canonists and theologians like Thomas Aquinas, ${ }^{6}$ and persists well into the eighteenth century, especially among modern natural law theorists such as Hugo Grotius, Samuel Pufendorf and John Locke. ${ }^{7}$ Although they did not phrase it in this language, the ultimate foundation given for such a right was the belief that every human being had a basic right to self-preservation. This right manifested itself as an individual right to take action either in a reactive way (in the form of self-defense), or in a proactive way (in the form of necessity). ${ }^{8}$

It is important to remark that the idea that necessity 'breaks through the ties of all laws' goes back to ancient times (Seneca famously made that claim ${ }^{9}$ ), and it was used to justify all kinds of otherwise wrongful acts if done in order to survive. For example, throwing the cargo overboard to prevent a ship from sinking, or feeding on human flesh when in the brink of famine. The novelty of the medieval and early modern accounts resides in that they enlarged the umbrella of necessity to include not only cases of one-off emergencies, but also cases of chronic deprivation. Although they did not always say so explicitly, this is what may be 
inferred from the examples given and from the social context that serves as a background to their writings. ${ }^{10}$

In an account such as that of Pufendorf one finds the idea that the exercise of the right of necessity is morally permissible when one's society does not even guarantee the minimal standards of material welfare for individuals either by means of justice or assistance.

Pufendorf asks us to consider the following situation: there is a government that makes no good provision for persons in want, while those who have the means to be generous do not behave benevolently, and the needy cannot get even the basic stuff for survival through work or other legal venues. In such a situation, he asks rhetorically, 'Must [the person] therefore perish with famine? Or can any human institution bind me with such a force, that in case another man neglects his duty towards me, I must rather die, than recede a little from the ordinary and the regular way of acting?' His answer is negative. The person may freely proceed. ${ }^{11}$

My interest in exploring the normative contours of the right of necessity thus understood is triggered, as I said at the outset, by the daunting numbers of people in extreme poverty and by the acute social and economic inequalities both intra and internationally. My ultimate aim, notwithstanding, is not to present this principle as a preferred course of action over the proposals of justice and assistance cosmopolitans, but rather as a necessary corollary of them; one that would have a very narrow scope of application if duties of justice and assistance were fulfilled at the domestic and global level. While this does not happen, however, and given the very limited access that the needy have to changing both the local and global structures and institutional arrangements that keep them in a state of deprivation, I grant that practices like shoplifting, pick-pocketing, urban squatting, rural illegal encampments and occupations could become so widespread that many could fear social chaos and disorder as a result. Rather than as a reason to reject the principle, however, I see this as a reason to take the basic tenets of moral cosmopolitanism seriously once and for all, and to rethink the potential consequences of current non-compliance with them. ${ }^{12}$

The scope of this inquiry differs from that of war cosmopolitans in two respects. First, I ask what poor individuals, rather than poor countries or collectives, may do to alleviate their need. ${ }^{13}$ Second, I ask what the needy may do not only against those who directly caused their plight or blatantly failed to fulfill the duties correlative to their basic subsistence rights, but also against (almost) anyone else, by virtue of our being part of one global society. Furthermore, the focus of this inquiry is different from the subset of assistance cosmopolitans who advocate forced assistance $e^{14}$ : by concentrating almost exclusively on what well-off third parties may do on behalf of the needy, these authors seem to start from the assumption that the latter are helpless creatures who require the aid of others in order to exercise their claims. By contrast, while I see the right of necessity as a transitive right that may be exercised by others on one's behalf (thus leaving open the possibility of forced assistance), I take the needy to be selfstanding agents whose independent role in a cosmopolitan morality has not been sufficiently explored. ${ }^{15}$

One more clarification is in place before proceeding. Some may point out that one need not go all the way back to the medieval and early modern accounts of the right of necessity, considering that this right is already recognized in most penal codes around the world, including the Model Penal Code and the common law of the U.S and the UK. In them, necessity is generally seen as a form of compulsion that works as an exculpatory reason when a person 
confronted with two evils avoids the greater one, which must be naturally caused. ${ }^{16}$ By restricting its scope in such a way, however, the law denies such a right to those who remain hungry and homeless due to the action of human third parties, individual or collective, and limits itself almost exclusively to one-off situations of need rather than to ongoing states of deprivation. The classic example is that of the otherwise lucky hiker who is caught in a mountain storm and must break into someone else's cabin in order to save himself. ${ }^{17}$ On the contrary, as I said above, the point of reviving the medieval and early modern conception of the right of necessity is that it expands both the origin and kind of need that make its exercise permissible. Here not only natural threats, but also human wrongs may trigger it, and not only one-off emergencies, but also ongoing states of deprivation may lead to its exercise. Unless I say so explicitly, it is on this conception of the right of necessity that I focus hereinafter.

The article unfolds as follows. First, I spell out my assumptions and refer to the content and form of the right of necessity. I then suggest three individually necessary and jointly sufficient conditions for its exercise, as well as two recommendations that ought to be followed inasmuch as possible by the potential claimants. Third, I present some scenarios where the right of necessity may be exercised in the global arena, and address a formal and a practical objection: that understanding this right as I propose it kills its intuitive plausibility, and that, even if we accepted it in principle, its application would be more damaging than beneficial. After rejecting these objections, I conclude that we should think of the right of necessity as a legitimate last resort for those in need while fairer and more equitable mechanisms of wealth redistribution at the domestic and global levels are not in place. At the same time, however, I acknowledge the limited possibilities for its exercise, especially in contexts where exercising it can come at a very high cost for the potential claimants.

\section{The form and content of the right}

Three normative assumptions and one empirical assumption underlie this project. First, my point of departure is moral cosmopolitanism, which rests on three tenets. First, individualism: individual human beings or persons (as opposed to nations, states or other sorts of collectives) are the ultimate unit of concern. Second, universality: every individual human being shares equally this status as an ultimate unit of moral concern. And third, generality: every individual human being is the ultimate unit of moral concern for everyone else. ${ }^{18}$

Second, I assume that all individuals hold certain basic rights, of which the right to subsistence is one. Combined with moral cosmopolitanism, this leads to the claim that, as members of one moral global society, we should recognize these basic rights on all others.

Third, I assume that property rights in whatever shape they come (private, collective, communal) are a salutary social arrangement that furthers some essential aims of the individual - like security and satisfaction of basic needs, more orderly and peaceful relationships with others, and the possibility to plan into the future. Because of these beneficial effects, it is reasonable for individuals to uphold property rules. Notwithstanding, fourth and lastly, if someone ends up destitute under a property scheme (the basic rules of which are justified precisely in terms of securing and providing at least a minimal threshold of material resources for everyone), then that person may not be expected to abide by those rules. This last clause therefore concerns the internal limits of any minimally reasonable property scheme. 
The empirical assumption, finally, is that within global society there are enough resources to satisfy everyone's basic right to subsistence. That is, I assume certain minimally favorable conditions, material and technological (in times of ecological catastrophe, presumably, other principles would apply).

My claim then is that, given certain individually necessary and jointly sufficient conditions, a chronically deprived agent has a right to take, use and/or occupy the resources required to get out of his plight, even if this implies encroaching upon someone else's property or territory. This right of necessity is the concrete, manifest expression of his individual right to subsistence.

In terms of its content, i.e. in terms of what the right of necessity is a right to, I limit it to those material resources required to guarantee one's subsistence, or to the means required to obtain them (paradigmatically, money). The kind of need that triggers the right of necessity is such that jeopardizes in a straightforward way the very self-preservation of the agent if he is not able to satisfy it. A list of basic needs according to this minimal specification include those physical, biological needs that we share with other animals, such as the need for food, water, sleep, protection from the elements and a place to be. These could be labeled as preinstitutional needs, in the sense that they exist independently of any social and/or legal arrangements, and their acceptance is relatively uncontroversial. ${ }^{19}$

In terms of its form, I understand the right of necessity to be composed of two different Hohfeldian incidents: a privilege to take, use and/or occupy whatever is needed by the agent in order to subsist, and a claim against others (including the owner of the resources targeted) not to interfere with her actions and to let her freely proceed.

In Hohfeldian terminology, if A has a privilege to $\varphi, A$ is free to $\varphi$, i.e. she has no duty not to $\varphi$. But having a privilege does not entail that A has a claim against other parties to $\varphi$. In the case in point, if the needy agent merely had a privilege to take, use and/or occupy the resources needed, this would mean that, given certain conditions, she would be morally free to do so; namely, to take, use and/or occupy some needed object $x$. This, however, would not correlate with any duties of the owner of $x$ or any other person for that matter. What is more, the agent's privilege to take, use and/or occupy the resources needed could well collide with the opposite privilege of the owner to defend his property against intruders, needy or not. ${ }^{20}$ This is why it is insufficient to understand the right of necessity as a privilege alone, and why it needs to be supplemented by a relational claim of non-interference against others. In the course of her dissection of Hohfeld, Judith Jarvis Thomson calls this a liberty proper: a cluster-right composed of two different incidents, and consequently stronger than a mere privilege. ${ }^{21} \mathrm{~A}$ liberty of necessity is therefore what this right amounts to.

An obvious worry at this point concerns the epistemic limitations of the duty-bearers. How is one, after all, supposed to distinguish between truly needy agents claiming someone else's or one's own property (and thus legitimately demanding not to be interfered with), and those who, while needy, and less well-off than the target, don't have the basis required? And for that matter, how is one supposed to distinguish between the truly needy and those who steal out of greed, for example? Is not such a principle technically overdemanding, in the sense that it requires agents to have the kind of knowledge or understanding of a given situation that is too difficult to demand? ${ }^{22}$ Another worry concerns the psychological demandingness for the dutybearers. For, what is one supposed to do if the needy repeatedly target one's own property, for example? How much of the brunt is one individual owner required to bear, especially when 
thousands of others are let off the hook?

My reply to this is threefold. First, regarding the technical overdemandingness of the principle, I admit that there will be many cases where it will not be fully transparent whether the agent claiming the property of third parties, or illegally entering a foreign country, is really in a state of necessity. In these situations, my advice for duty-bearers is to err on the side of caution and refrain from interfering. The underlying thought is that, morally, it is better to be a sucker than to prevent someone from satisfying his most basic needs.

The fear that the cost for the potential duty-bearers will not be small, but significant, leads to the second worry: psychological overdemandingness. Say, for example, that a group of homeless people decide to move in to my house, without requiring me to leave. Is my duty to make space for them all? Or do I get to say 'Why me? How about that empty house down the street instead? ${ }^{23}$

Two things need to be said here. One is the importance of distinguishing between immediate and final duties. When it comes to the fulfillment of the right of necessity, whoever is in a position to refrain from interfering ought to do so, bearing the immediate costs of so doing, and even if these costs include the loss of one's own property. This immediate duty ought to be borne due to the moral weightiness of the right at stake. But this does not settle the equally important question of who ought to bear the final duty of compensating those who complied with their immediate duty or, better still, of ensuring that no one falls into dire need in the first place. Here I can only sketch out a quick response, which is that final duties ought to be distributed among all potential duty-bearers according to some fair-share principle that takes into account, for example, the latter's capacity to influence structural processes that keep people in a state of deprivation, the extent to which they benefit from these very same processes, the degree to which they have an interest in modifying these processes (which turns the needy themselves into agents with a relevant role in reshaping these processes), and their ability to organize collective action for change. ${ }^{24}$ It goes without saying that final duties should ultimately be directed not at compensating those who end up individually bearing duties that ought to be collectively borne, but first and foremost at preventing people from falling in dire need. It must be reminded, however, that the whole point of writing an article defending the exercise of the right of necessity is precisely as a response to a systematic failure in allocating these final duties. Dissolving the worry of psychological overdemandingness, therefore, lies not in denying this right to the needy, but in confronting heads-up the question of how to build a global society where the fulfillment of everyone's basic right to subsistence is guaranteed.

My other response to the worry of psychological overdemandingness is that those claiming their right ought to follow inasmuch as possible two recommendations, one of which has to do with the profile of those whose property ought to be preferably targeted. The objective of this recommendation is to minimize the likelihood of situations like the one above (where homeless people take over an already inhabited house), so that complying with the immediate duty correlated to the right of necessity does not become overly taxing. I explain this in more detail at the end of the next section.

\section{Three conditions}

I propose three individually necessary and jointly sufficient conditions for the right of 
necessity to be exercised by the chronically deprived. I also add two recommendations geared at both minimizing potential conflict and at diminishing the likelihood that bearing the immediate duty will be too demanding for those whose property is targeted by the needy.

A first condition is that the need in question is basic. As was said above, it is of a kind that has to be fulfilled for the agent to preserve himself. The list of needs and material objects that fall under this denomination was already expounded when discussing the content of the right, so I will not repeat it here.

A second condition is that the needy person may not, through the exercise of her right, violate other equally important moral interests. This is a blocking condition that rules out two possibilities: on the one hand, it prevents the needy person from exercising her right against someone equally needy or almost as needy in the same relevant respect; on the other hand, it prevents the needy person from exercising her right in such a way that compromises other equally important moral interests, such as other people's basic liberties or security rights. Excepting saints and heroes, and persons connected by strong special ties (like mother and child), no one should after all be expected to abide by a clause that compelled him to willingly let someone take his last loaf of bread without trying to impede it. ${ }^{25}$

Third, the right of necessity kicks in as a last resort, after other paths of action (if there have been any) have been pursued unsuccessfully. These paths may include offering one's work and services, directly asking for help, and appealing to the relevant authorities, and they should be reasonable in two ways: they should be limited to those courses of action that the agent may undertake with a likely expectation of success; and they should not be overly taxing for the agent in a way that would violate other equally important moral interests that she may have (an extreme example of this would be to enslave oneself in order to be guaranteed the basics for survival).

I suggest moreover that the potential claimants ought to follow inasmuch as possible two recommendations geared at diminishing conflict, and at minimizing the likelihood that complying with the principle becomes overdemanding for the immediate duty-bearers.

First, to diminish the possibility of conflict with the owners of the targeted resources, potential claimants should act covertly rather than overtly, especially if they anticipate that others will interfere with their actions. ${ }^{26}$ Meanwhile, in cases where there is no alternative and the needy are faced with the resistance of others in the course of their acting, the use of force should be kept to the minimum, and take into account mitigating circumstances, such as the lack of relevant knowledge that the duty-bearers may have regarding the situation, the economic burden that the taking will represent for the owners of the targeted resources, the number of times that the latter have already been targeted by other needy agents, etc. ${ }^{27}$

The second recommendation is that whenever possible and for reasons of fairness, the needy should target the resources of those who will be least affected by the loss. This can be met by following two criteria: 'The agent has a good reason to believe that the intended target of appropriations has not already come under pressure such as to constitute a morally important burden for him', and 'the agent has a good reason to believe that the position of the intended target of appropriations relative to others above the threshold is as high and/or as comfortable as possible'. ${ }^{28}$

Having said this, it is important to underline that these recommendations should be that and 
no more, especially if one bears in mind that targeting those higher up may be more costly for the needy agents. ${ }^{29}$

\section{Contemporary applications and two objections}

With these three conditions and two recommendations in mind, one can ask in what kinds of settings the right of necessity may be invoked today. I suggest three: a hungry child living in a poor neighborhood in a developing country takes the wallet of an inadvertent tourist in order to buy some food. A group of homeless, unemployed people in a country amidst a deep economic and social crisis find shelter in an empty building and squat there. A person flees her country of origin due to the absence of economic opportunities that keep her in a state of permanent deprivation.

In these cases, the normative force of having a human right to subsistence materializes, while the well-known complaint against basic human rights being manifesto rights evaporates. Here, there is no unspecified duty-bearer against whom the agent's claims should be lodged, and the right-holders are not seen 'within an overall framework of recipience'. They do not 'demand that others act rather than that they do so themselves'. ${ }^{30}$ On the contrary, the relevant agents are the needy themselves targeting specific property belonging to specific people. There are, that is, clear duty-bearers (at least, as was said before, in the sense of agents bearing the immediate duty not to interfere with the former's actions).

But some will object that extending the scope of the right of necessity as I have proposed it kills its intuitive plausibility; namely, above all as an exceptional resort for persons amidst ad hoc, naturally-caused crises (which is, to recall, how ancient jurists understood it, and how contemporary lawyers understand it). That theorists from Alanus to Pufendorf missed this point and subsumed under the necessity umbrella cases of chronic and human-caused deprivation is a problem for their accounts rather than a reason to follow them! I call this the formal objection. Furthermore, even if one accepted that, in principle, the right of necessity may be thus extended, one could object that its application would bring such unwelcome consequences for the needy agents, the owners of the targeted resources, and, ultimately, society at large, that it should be dismissed. I call this the practical objection.

To take the formal objection first. There are at least four relevant differences between the cases proposed and those where the right seems intuitively plausible, the objection would go. The latter are urgent situations that may affect anyone and come about in an unforeseeable manner, so that the agent can do nothing to prepare for them or avert them. Moreover, the right of necessity ought always to include a restoration-clause whereby, after being relieved from immediate danger, the agent should compensate the owner of the targeted resources. On the contrary, the cases presented do not meet these conditions. Here the claimants are not just anyone in a uniquely urgent situation, but the systematically poor on a foreseeable, daily basis, and with no intention to restore what they take. Bearing these disanalogies in mind, the objection would conclude, it seems a wrong-headed enterprise to try and approach the problem of global poverty via the right of necessity, stretching the latter in an undue manner.

The question, however, is whether these are morally relevant disanalogies. I propose that they are not and that, if we concede this, the door opens for a multiplication of necessity claims worldwide.

A first, obvious point, is that I have no quarrels with the idea that the exercise of the right of 
necessity should be available for everyone as a last resort. Focusing on the plight of the chronically deprived does not imply disregarding the claim of those in an unexpected emergency.

Second, regarding the distinction between single, urgent events versus everyday, permanent states, the point cannot be that the chronic hunger suffered by the poor child day after day is not as morally relevant as the unique hunger suffered by the otherwise lucky hiker caught in the mountain storm. Likewise, it cannot be that we find it morally permissible for the latter to break into someone's cabin until the storm recedes, but not for the squatters to take refuge in an empty property until the social and economic conditions of their country improve. If there is a moral disanalogy between cases, it cannot be attributable to the kind of need at stake, i.e. continuous versus fleeting.

Maybe the claim that it is significant that in one case the necessity is brief and arises suddenly, and in the other it is ongoing relates to the fact that, if ongoing, it should be possible to address the problem without resorting to violating the standard legal rules. However, this begs the question: as repeatedly mentioned, the whole point of arguing for a right of necessity for the chronically deprived is precisely that the problem has not yet been addressed. Or maybe the claim is that ongoing situations of deprivation are hopeless, so that no one should be required to let the needy act on their own initiative. This claim, however, goes against the generality principle of moral cosmopolitanism, where every individual is an ultimate unit of moral concern for everyone else. Still, perhaps the point is a practical consideration, such as that letting the exercise of the right of necessity go unfettered among the world's poor would make it overly demanding and unfair for the owners of the targeted property, especially if the claimants are blind to considerations such as the latter's relative position to each other; or to the amount of times that the latter's property has already been targeted by other needy individuals. I address this practical objection below.

Third, regarding the claim that foreseeability is morally relevant, clearly it is morally relevant if it makes a difference to what agents can actually do about the upcoming course of events, but not if it doesn't. In other words, foreseeability ought to matter only when it can matter. To put an example, astronomers today may well foresee that an asteroid is going to hit the Earth next year, destroying life in the planet. It does not follow from this, however, that they have no right of necessity to board a spaceship that will leave the planet before the impact, just because they knew that this was going to happen a year in advance rather than minutes before! Analogously in the cases offered above, the agents may respectively foresee their hungry, homeless and stateless future lives, without having the tools to avert the impending doom. ${ }^{31}$

Finally, the following distinction explains why restoration seems out of place in cases of chronic necessity. ${ }^{32}$ On the one hand, when a person invokes urgent necessity, she is not putting into doubt the validity of the rules of property, but asking to be treated as an exception. Given the over-inclusiveness of the said rule, following it in that particular situation would run counter to the very objectives for which it was created. Compensating for the damages caused is thus a way of showing one's respect for the general rule, which in this specific case had to be skipped. On the other hand, when a person invokes chronic necessity, her acts ultimately question the very rules that keep her in a state of deprivation. That is, she openly violates the rules on the assumption that no one may be forced to abide by them if being so forced prevents her from satisfying her most basic needs. Therefore, no restoration is 
due. This, of course, does not preclude the possibility that needy agents show their gratitude towards those bearing the immediate duties, especially if they live in an environment averse to the exercise of this right and still choose to condone it.

Summing up, while I grant that the disanalogies between the two types of case may affect our first-hand moral responses toward them, on closer examination they do not seem to merit a different moral treatment. They are not, in short, morally relevant disanalogies.

Still, even if one accepts this, one may object that the exercise of the right of necessity as a shortcut for the global poor to fulfill their basic needs would bring about such bad consequences that it ought to be dismissed as a remedy worse than the disease. I divide this practical objection into three parts: the creation of a moral hazard, the bad effects for both potential claimants and duty-bearers, and the bad effects for society at large.

One could first object that acceptance of this principle would create a moral hazard, discouraging individual industry by removing the incentive to increase one's own property. For, why bother to accumulate if the product of one's efforts may become the target of the needy again, and again, and again?

The worry of creating a moral hazard rests on an empirical assumption; namely, that property owners would lose their economic incentive if claims of necessity multiplied. But this empirical claim might well be contested and pitted against another; namely, that property owners would instead come to realize that it is fairer social and economic arrangements globally that would put an end to their fears of being targeted by the needy, so that those who can should join efforts toward attaining these arrangements.

A second objection is that it would be unfair for the owners of the targeted property, and especially for the poor themselves: because of feasibility constraints, it will probably be the case that those in need will take again and again from those who are just a bit above them, but not much, rather than from the wealthy and powerful, whose property is much more difficult to access. This is a fact that human geographers will confirm: especially in developing countries the poor live side by side with the poor, while the better-off live secluded and well protected from the former. By allowing the liberal exercise of this right, the poor would keep stealing from the poor. Worst of all, allowing claims of necessity to proliferate would not even be desirable for the right-holders: because the principle only allows to take, use and/or occupy just enough to get out of their plight, the needy would keep falling under the threshold and resorting to this moral prerogative endlessly, with no overall benefit except that of bare survival.

While I fully recognize these dangers, I do not see them as an argument against allowing the needy to claim what they need to survive, but rather as a reminder that global structures that keep people in a state of deprivation have to be changed. It has to be noticed that the right of necessity is not primarily about achieving social fairness, but individual survival. It would be adding insult to injury to request those whose very self-preservation is at stake to fight for a better world, or to fight for improving the social conditions for everyone at the cost of submitting themselves to living under conditions that threaten their very subsistence. In short, although I concede that claiming necessity is far from being the optimal solution to chronic deprivation, I do think that one has to accept it as a legitimate escape valve for those who do not have anything else to resort to in the meantime. 
A third practical objection invites us to imagine what would happen if the right of necessity were widely claimed in our global society, in a disorderly and uncoordinated fashion. Social chaos and even breakdown would follow. Among other bad consequences, people would live under a general feeling of fear and insecurity; there would be even less charitable dispositions (why be generous to the needy, if they may turn up any day and take one's property away?); social division within and between countries would worsen, as would the stigmatization of the poor; industries such as tourism in developing countries would decline, having a negative impact on their economies; and the industry of private security would flourish, resulting in ever more repressive and vigilante societies. As Lord Denning famously put it in London Borough of Southwark $v$ Williams, 'if hunger were once allowed to be an excuse for stealing, it would open a door through which all kinds of disorder and lawlessness would pass.' ${ }^{33}$

I am sympathetic to this position, but again, even if it were true that the short and mid-term consequences of having such a right exercised routinely at the global level would be bad (even as bad as suggested above), the answer should not be to ban the exercise of the right. Rather, it should be to start striving for a minimally decent basic social structure, domestic and global, that secures everyone's self-preservation. Eventually, in such a society the right of necessity would indeed be limited only to cases of one-off urgent need.

\section{What the old right of necessity can do for the contemporary global poor}

Over three centuries ago Pufendorf already saw the need of guaranteeing to every member of society at least certain minimal welfare provisions, while acknowledging that failure to do so may result in the person legitimately exercising her right of necessity, as the concrete, ultimate expression of her most basic right to self-preservation. At that point in time, the system of nation states was just coming into shape and the concept of a global society was far from being coined, but the idea that all persons were equal holders of certain basic rights and equal bearers of certain minimal duties to each other was becoming a shared assumption in moral and political philosophy. Although he did not spell it out in these terms, Pufendorf's underlying thought was that, in a society that complied with some basic requirements of social justice, appeals to necessity would be truly exceptional and probably limited to hiker-in-thestorm kind of scenarios. In the absence of such compliance, however, no one should expect the needy to refrain from taking from others the basics for their subsistence.

In concluding, I would like to take Pufendorf's rationale to the global level and suggest that, so long as certain minimal welfare provisions are not secured for everyone, everywhere, the exercise of the right of necessity should be accepted in a variety of scenarios, however uncomfortable its implications. Even if one grants that the solution for global poverty will not come from the disorganized, uncoordinated actions of needy individuals grabbing the property of third parties and illegally making their way into foreign countries, at least this much should be conceded if one does not want to turn the human right to subsistence into wishful, but empty rhetoric. 
Thanks to Marcia Baron, Simon Birnbaum, Stephanie Collins, Alfonso Donoso, Göran Duus-Otterström, Manuel Toscano, two anonymous referees and the editor of this journal for written comments on earlier versions of this article. I am also grateful to Christian Barry, Tom Campbell, Bob Goodin, Christel Fricke, Virpi Mäkinen, Thomas Pogge, and Kerstin Reibold for illuminating discussions on this topic, as well as to the audiences at the following seminars and conferences where I presented this work at different stages: Responding to Global Poverty (CSMN, University of Oslo), PPPE Club (University of Oslo), Realizing Global Justice (Arctic University of Norway), MANCEPT workshop on Global Justice: Radical Challenges (Manchester, UK), philosophy seminar (University of Bergen), and seminars of political science at the Universities of Aarhus (Denmark), Stockholm and Göteborg (Sweden), and Universidad Católica (Chile). I am especially grateful to the Society for Applied Philosophy, which provided me with funding to organize the workshop 'A place for the old right of necessity in the contemporary debate on global poverty' (CSMN, University of Oslo). It goes without saying that the arguments presented do not necessarily do justice to their views and suggestions, but are wholly attributable to my stubbornness. Finally, it must be mentioned that this work was partly supported by the Research Council of Norway through its Centres of Excellence funding scheme, project number 179566/V20.

1 Regarding poverty, according to the most recent data 836 million people live today with less than 1.25 USD a day (United Nations, The Millenium Development Goals Report 2015,

http://www.un.org/millenniumgoals/2015_MDG_Report/pdf/MDG\%202015\%20rev\%20\%28July\%201\%29.pdf. The UN's World Food Program informs that 'some 805 million people in the world do not have enough food to lead a healthy active life. That's about one in nine people on earth' (UN's World Food Program, https://www.wfp.org/hunger/stats). 750 million people pack access to clean water, and every minute a child dies of a water-related disease (Water Organization, 'Millions lack safe water', http://water.org/water-crisis/water-facts/water/. Regarding wealth inequality, it is estimated that the richest $1 \%$ of adult wealth holders now own half of all household wealth, reaching levels not seen for almost a century (Credit Suisse Research Institute, Global Wealth Report 2015, http://publications.credit-suisse.com/tasks/render/file/index.cfm?fileid=C26E3824-E868-56E0CCA04D4BB9B9ADD5), all accessed October 252015.

2 See Thomas Pogge, World Poverty and Human Rights: Cosmopolitan Responsibilities and Reforms, second ed. (Malden, MA.: Polity Press, 2008).

See Peter Singer, The Life You Can Save (Melbourne: Text Publishing, 2009).

4 See David Luban, 'Just war and human rights', Philosophy \& Public Affairs 9, 2 (1980), pp. 160-81; Cécile Fabre, Cosmopolitan War (Oxford: Oxford University Press, 2012), pp. 97-129; and Kasper Lippert-Rasmussen, 'Global injustice and redistributive wars', Law, Ethics and Philosophy (LEAP) 1,1 (2013): 65-86.

5 See Peter Unger, Living High and Letting Die (New York: Oxford University Press, 1996); and Gerhard Øverland, 'The Right to Do Wrong', Law and Philosophy 26, no. 4 (2007), pp. 377-404.

6 Thomas Aquinas, Summa Theologiae II-II, Question 32, Article 5, in Aquinas Ethicus, vol. 2, (London: Burns and Oats, 1892). For a complete overview of the medieval discussion, see Virpi Mäkinen, 'Rights and Duties in Late Scholastic Discussion on Extreme Necessity," in Virpi Mäkinen and Petter Korkman (eds.) Transformations in Medieval and Early Modern Rights Discourse (The Netherlands: Springer, 2006), pp. 37-62.

7 Hugo Grotius, The Rights of War and Peace, ed. Richard Tuck (Indianapolis: Liberty Fund, 2005), II.II.VI, 433-37; Samuel Pufendorf, Of the Law of Nature and Nations, trans. Basil Kennet, fourth ed. 8 vols. (London: Printed for J. Walthoe, 1729) II.VI, pp. 202-212; and John Locke, Two Treatises of Government, ed. Peter Laslett (Cambridge: Cambridge University Press, 1988), I.§42, p. 170. For a thorough account of the historical evolution of this right, see Scott G. Swanson, 'The Medieval Foundations of John Locke's Theory of Natural Rights: Rights of Subsistence and the Principle of Extreme Necessity', History of Political Thought 18, 3 (1997), pp. 400-58.

8 What is more, these authors understood the right of necessity also as a duty towards God: letting oneself die out of hunger was therefore not a permissible option. In my own, secularized account, I leave it open to the needy individual whether to exercise her right or not. See section 2 below.

9 Quoted in Grotius, op. cit. p. 435.

10 The English canonist Alanus, for example, claimed that 'the poor man did not steal because what he took was really his own iure naturali - which could mean either "by natural right" or "by natural law"'. Laurentius Hispanus wrote that when the poor man took what he needed, it was 'as if he used his own right and his own thing', and the English jurist Hostiensis stated that 'one who suffers the need of hunger seems to use his right (ius suum) rather than to plan a theft'. All quoted in Brian Tierney, 'Origins of Natural Rights Language: Texts and Contexts, 1150-1250,' History of Political Thought 10 (1989): 615-46, p. 642.

11 Pufendorf, op. cit. II.VI.v, p. 207. Unfortunately, Pufendorf does not clarify what is involved in receding a little from the ordinary and regular way of acting.

12 Instead of fearing the potential chaos that could result if all the needy claimed their right of necessity, some may complain here that theoretically empowering the needy will make little difference in practice, given the serious risks involved in exercising their right (confronting the police and other armed forces, being subject to physical abuse and 
even death, ending up in prison, being further marginalized and discriminated, etc.). I fully see this limitation, which is why I underline time and again that the right of necessity is not a panacea for global poverty, but the only option immediately available for many - something that should ultimately serve as a wake-up call to sort out final duties concerning global structural injustices. I thank an anonymous referee for pressing me to clarify this point.

13 War cosmopolitans have tended to assume that countries may in fact be divided into rich and poor and have ignored, for the sake of argument, the socioeconomic differences within them. On the contrary, I take this assumption to be an undue idealization that damages their whole project and weakens its plausibility. I borrow this term from Gerhard Øverland, 'Forced Assistance', Law and Philosophy 28 (2009), pp. 203-232.

To be fair, there are some theorists who have posed the question of what the needy may do, especially to change the unjust structures that keep them in a state of ongoing deprivation and oppression. Monique Deveaux, for example, has defended the role of the poor as active political agents in collective efforts of poverty reduction, while Roberto Gargarella has theorized about the right to resistance of the needy under such conditions. As theorists of poor-led movements, however, both omit the question of what the needy may do as moral agents individually exercising their basic rights. Cf. Monique Devaux, 'The global poor as agents of justice', The Journal of Moral Philosophy 12, 2 (2015): 125-50, and Roberto Gargarella, 'The right of resistance in situations of severe deprivation', in Thomas Pogge (ed.) in Freedom from Poverty as a Human Right (New York: Oxford University Press, 2007): 359-74.

16 Joshua Dressler, 'Exegesis of the law of duress: justifying the excuse and searching for its proper limits', California Law Review 62 (1988), pp. 1331-1386, p. 1347 ff.

17 The example appears in Joel Feinberg, 'Voluntary euthanasia and the inalienable right to life', Philosophy \& Public Affairs 7, 2 (1978): 93-123.

18 Pogge, op. cit, p. 175.

19 This is a much more minimal account than the one provided in the Article 25 of the Universal Declaration of Human Rights: 'Everyone has the right to a standard of living adequate for the health and well-being of himself and of his family, including food, clothing, housing and medical care and necessary social services, and the right to security in the event of unemployment, sickness, disability, widowhood, old age or other lack of livelihood in circumstances beyond his control' (Universal Declaration of Human Rights, Article 25 (1), http://www.un.org/en/documents/udhr/index.shtml\#a25, accessed March 11, 2015.

20 Wesley Newcomb Hohfeld, 'Some fundamental legal conceptions as applied in judicial reasoning', The Yale Law Journal 23, 1 (1913): 16-59, p. 36.

21 Judith Jarvis Thomson, The Realm of Rights (Cambridge, MA.: Harvard University Press, 1990), p. 54.

22 The concepts of technical and psychological overdemandingness are from Jan-Christoph Heilinger, 'The moral demandingness of socioeconomic human rights,' in Jan-Christoph Heilinger and Gerhard Ernst (eds.), The Philosophy of Human Rights. Contemporary Controversies (Berlin: de Gruyter, 2012), pp. 185-208.

23 I thank Marcia Baron for putting this example.

24 Iris Marion Young proposes these four parameters when deciding how to allocate responsibilities in response to unjust structural processes of which we all partake. Iris Marion Young, 'Responsibility and global justice: A social connection model', Social Philosophy and Policy, 2006, 102-30, pp. 125-30.

25 Some may suggest that in one-to-one settings of deprivation the owner of the sought resource ought to accept tossing a coin and let luck decide who gets the needed object. It seems to me more accurate to say that, in scenarios of this kind, what agents have is a mere privilege, rather than a full-blown liberty of necessity. I thank an anonymous referee for pressing me to clarify this point.

26 It is not by chance that successful shoplifters and pickpockets are those that act covertly rather than overtly. When it comes to squatting and illegal encampments, meanwhile, agents normally tend to follow the second, two-tiered recommendation, targeting empty rather than inhabited buildings or land, which are legally owned but many times forgotten by their well-off owners. Just to mention one example. During the 1950s-1970s, it was a common practice of urban homeless families in Santiago, Chile, to settle in empty patches overnight to avoid confrontation with the police and with the legal owners. As more families arrived, a población callampa (literally, mushroom settlement) emerged. See Alejandra Mancilla, 'Las poblaciones callampas como expresión del derecho de necesidad', in Christian Barry, Alejandra Mancilla and Eduardo Rueda (eds.), Reclamo de tierras en América Latina. Legitimidad moral e implicaciones (Bogotá: Editorial Javeriana, forthcoming).

27 More work surely needs to be done to pin down more precisely how much force the needy may use, but looking at the literature on proportionality in the use of force in self-defense should give us a good hint of what the upper limit should be (this is bearing in mind that self-defense and necessity are two expressions of one and the same basic right to selfpreservation).

28 I thank Gillian Brock for suggesting this.

29 This is why I choose to omit a third criterion as part of the last recommendation, namely, that 'the agent has a good reason to believe that the intended target of appropriations has directly contributed to his plight'. Although this would clearly be the fairest course of action, directly connecting the aggressors/oppressors with their victims, I think in the real world the chances for the needy to do this successfully are dim - which leads us, yet again, to the critical question of 
allocating final duties.

30 Onora O'Neill, 'Rights, Obligations and Needs', in Gillian Brock (ed.) Necessary Goods (Boston: Rowman \& Littlefield, 1998), pp. 95-112, at p. 97.

31 What is more, foreseeability is not even morally decisive in cases of urgent need. For example, if the lonely hiker were reckless enough to go into the mountains even after having checked the ghastly weather report, he would still have the right to break into the hut to save himself. That we could find his actions morally reprehensible and make more stringent demands upon him ex post is a different matter, of course.

32 For the distinction, see Jeremy Waldron, 'Why indigence is not a justification,' in William C. Heffernan and John Kleinig (eds.) From Social Justice to Criminal Justice: Poverty and the Administration of Criminal Law (Oxford University Press, 2000), pp. 98-113.

33 Alan Brudner, 'A Theory of Necessity', in Oxford Journal of Legal Studies 7, 3 (1987), pp. 339-368, at p. 340. 